\title{
Design of Rescue Robots with a Morphological Environment
}

\author{
Roman Zinko, Lviv Polytechnic National University
}

\begin{abstract}
The morphological environment, which models the human brain, is encouraged to be used by creating a mobile rescue robot. The use of such media will manage and organize large amounts of knowledge required for the design of new cars. Morphological environment should be of a certain structure, and to create new designs of machines it is reasonable to apply a special algorithm for the synthesis and improvement of existing machines and mechanisms using global and local performance criteria. An example of improving the design of mobile robot caterpillar engine is given in the paper.
\end{abstract}

Keywords: Algorithm of the synthesis of vehicle construction, global and local efficiency criteria, knowledge arrays, mobile rescue operations, morphological environment.

\section{INTRODUCTION}

Searching for victims and providing first aid - the main tasks of rescue workers in the aftermath of emergencies. One option for the effective implementation of this task is the use of mobile rescue robots [1-2]. Such robots are created on the base of mobile platforms, which set the detectors and other equipment. The creation of the vehicles of such class is carried out by the method of attempts and mistakes that does not have a verified and efficient methodology of projecting of these vehicles. At the same time, there is the necessity not only of the quick creation, but also of the wide usage in the conditions that are dangerous for people.

Rates of change of generations of the technical decisions started to advance considerably rates of change of generations of their establishers. Nowadays, the change of several generations of the technical means in the leading branches of production has been carried out during labor activities of one specialist. This rapid technical modernization leads to the same rapid aging of accumulated knowledge base. This requires its frequent and rapid modernization. However, the developers are facing increasing demands and new challenges. The constructor has to extend his knowledge continuously and improve his skills, in terms of not only narrow specialization, but also taking into consideration experience and technical capabilities of progress, in order to keep abreast with technical areas of technology. Huge amount of scientific, technical, industrial and technological information available on the Internet and which is provided by scientific, technical, research institutes and industrial laboratories especially helps to fulfill the modernization of knowledge.

\section{THE ANALYSIS OF RECENT STUDIES}

All stages of development of new techniques can be grouped into four main phases, which in general terms describe the whole "life" cycle of the created product: conceptualization, design, construction, implementation [3].

In the phases of planning, design and implementation, the software environments are designed and developed that can facilitate the work of researchers, designers, engineers and operators. There are the following mathematical modeling environments: MathCad, MatLab, Matematica, Maple, Dymola, Computer Aided Design AutoCad, CATIA, T-FLEX CAD, Compass, ANSYS, Unigraphics, Pro/ENGINEER, SolidEdge, SolidWorks, database management systems Microsoft Access, Paradox, dBase, Visual FoxPro, Oracle, MS SQL Server.

In the phase of conceptualization, as a rule, only phenomenal and logistic design methods are used (heuristic methods, iterative methods, morphological analysis, decomposition, methods of the theory of inventive problem solving). Attempts to create an environment for the processing of large amounts of knowledge, not only just the information, have not achieved great results [4].

Phenomenal and logistic description of the human mind imposes substantial restrictions on research, analysis and use of knowledge related to the activities of the society [5]. Attempts to use the achievements of modern mathematics attain local results [6-8].

One of the effective ways of knowledge organizing and structuring is the creation of knowledge environments (or morphological environments) that would allow simulating human thinking to create new machinery and study their operation [9], [10].

\section{General Regulations}

Interconnections of the constituents and peculiarities of the environment operation can be reflected with the help of graph. The structure of a graph can be represented as a table that will help to form the final formula of the environment operation.

The external world is defined as a set of sets $\{\Omega, \Sigma, U\}$, where $\Omega$ - set of objects of the external world; $\Sigma$ - signature - a set (list) of relations and objects location; $U$ - axiomatics - a set, which is given on the sets $\Omega, \Sigma$.

The objects of the external world (multidimensional information outside) through the reception reflected in morphological environment (ME) on the set (Fig. 1). 


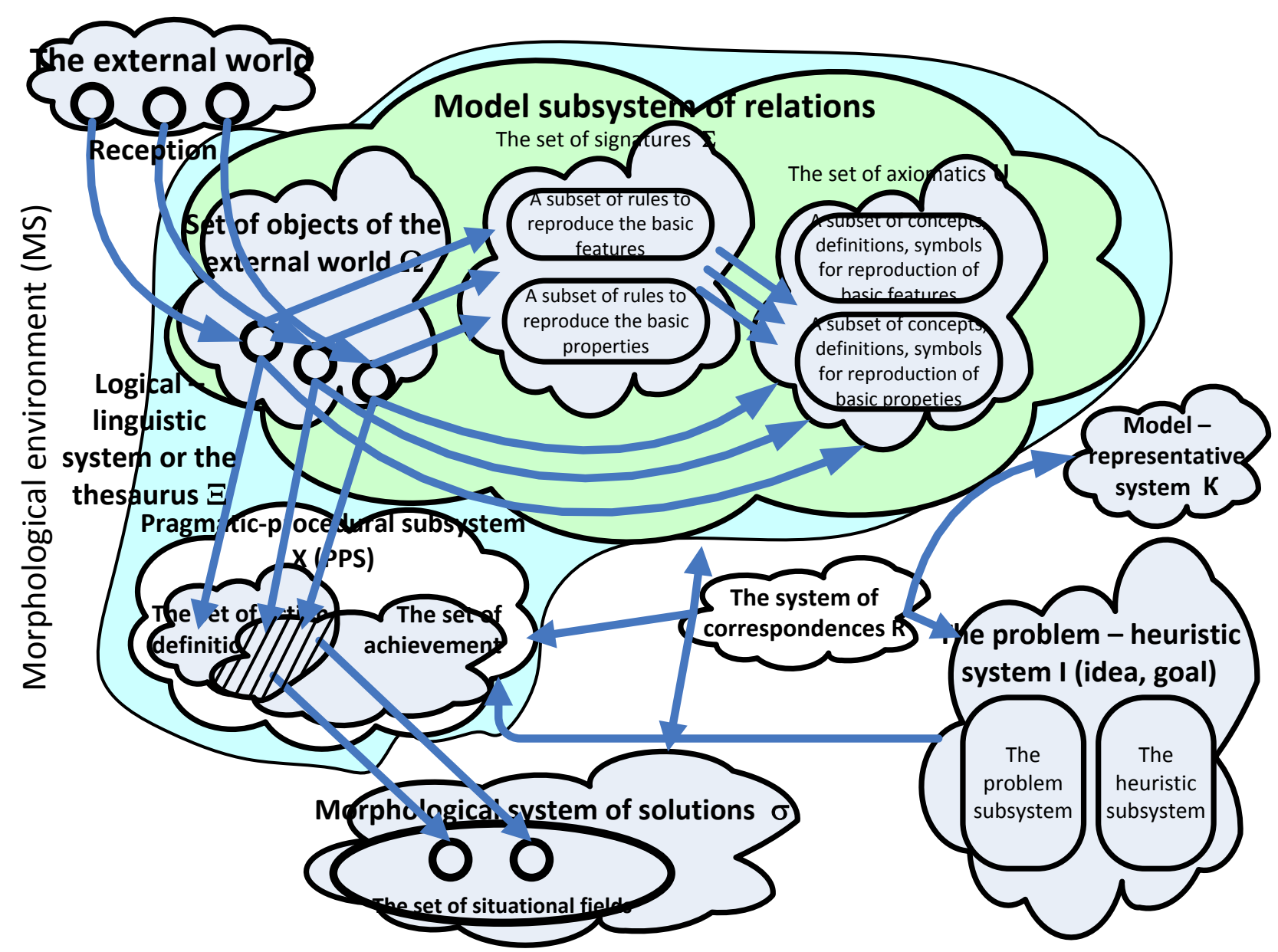

Fig.1. Interconnection of the components in the morphological environment.

Under such circumstances, the model subsystem of the relationships (MSR) or location (place) of objects in MS $\Omega$. MSR contains the set of object reflection (SOR), its signature $\Sigma$ and axiomatics $U$. Signature $\Sigma$ - a group of rules that set the procedure of comparison. Signature contains a set of rules for the reproduction of the basic characteristics and properties, sets of rules for constructing expressions of the elements included in the alphabet. Axiomatics (dictionary) $U-$ the fundamental concepts that describe properties of objects. Axiomatics contains sets of concepts, definitions, symbols for the reproduction of the basic characteristics and properties, a set of concepts, definitions, symbols and signs by which the language alphabets in morphological environment are formed.

Pragmatic-procedural subsystem X (PPS) is the subsystem, which provides various conversions, operations and actions with the components from all major subsystems of the theory, as well as procedures and rules of the performance of these actions. At the same time, it includes various axiological evaluations of various components of the space, as well as phenomena and objects in its visual field. Logical and linguistic system or thesaurus contains MSR and PPS X.

Model - representative subsystem $K$ reflects area of the investigated reality with the help of conceptual models. With its help the phenomena and objects, represented by their models, correlate with different levels of hierarchy within this subsystem. The next levels can be defined: 1) experimental models (containing information about the objects, obtained without the use of ME), 2) the full model (which is described with the help of the conceptual apparatus ME), 3) models own ME (for whom the laws are executed ME) and 4) the restrictions, presented by a special subset of the great number of full models.

The main function of problem-heuristic subsystem $I$ lies in the reflection of those sides of $\mathrm{ME}$, which are connected with obtaining new knowledge.

In its turn, the problem-heuristic subsystem is divided into two parts: a heuristic, which includes non-formalized (i.e., intuitive) methods of obtaining new knowledge, and a problem part, which includes tasks, problems and questions as well as hypothesis. All these elements correspond to different methods and ways of solution of emerging problem situations, derived from the results of their help, etc.

Interconnections between these subsystems are represented in the subsystem of correspondences $R$. It reflects the fact that description of the model of various kinds has been carried out with the help of logical and linguistic system $\Xi$, or the fact that practical problems decided with the help of theory are usually formulated on certain models or, for example, that the 
statements that appear as a problem solution on the properties of models in their assessment require an appeal to the pragmatic and procedural subsystem.

Algorithm of the synthesis and improvement of the existing vehicles includes a morphological environment as a separate element (Fig. 2). If economical use of resources is not always necessary to produce the highest quality products, results should be formed based on the performance criteria specified in a particular task.

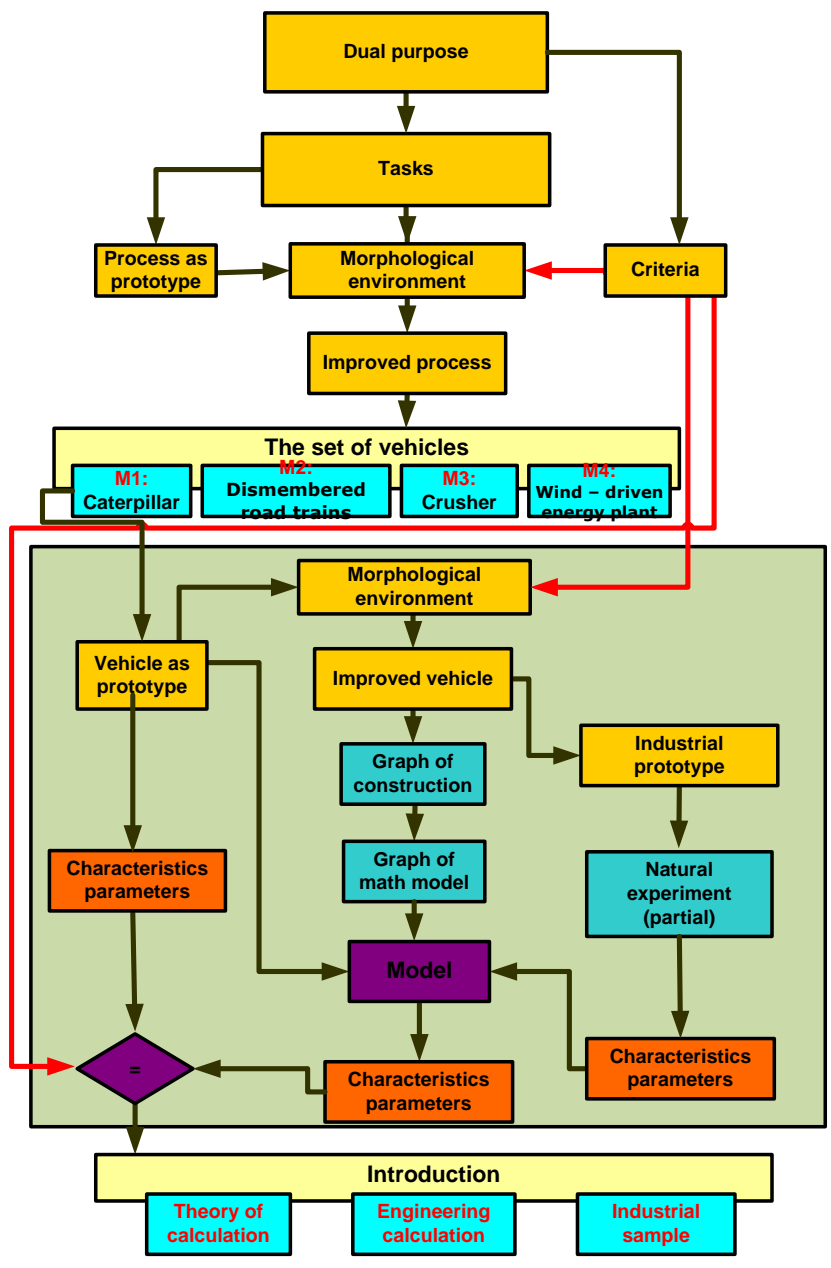

Fig. 2. Algorithm of the synthesis and improvement of the existing vehicles.

The peculiarity of the algorithm is the usage of morphological analysis principles, taking into consideration features of the investigated object. As there may be many signs for the reduction of labor costs, the screening of minor characters is carried out based on the selection criteria.

The current set of characteristics is formed with the help of matrix in the knowledge base. Herewith it is helpful to write the following major sections as an aggregate state, its changes within certain limits obtained by this effect, the index of the effect, technical, operational and economic performance of the effect.

Feature of the investigated object has the appropriate characteristics (Table 1).

Improvement of the machine is based on an accepted criterion. Depending on the adopted criteria, it is possible to obtain a machine with significantly different characteristics eventually.

Criteria are the technical parameters of the object, which vary monotonically for a long time, approaching their limit, and they are the indicators of excellence and progress.

Technical facilities are improved in the direction of criteria improvement. Since the quality of any machine is rated on several criteria, the principle of progressive development lies in improvement of one or deterioration of other criteria [9]. To assess the quality of machines, authors use four groups of criteria: functional, technological, economic and anthropological (Table 2).

Total number of criteria used to evaluate machine technology cycles can be divided into two groups: general for all cases (global) and criteria specific to individual cases (local).

The most important global criteria are the following: an increase in the automatization level of key operations; an increase in the level of mechanization and automatization of support operations; the improvement of the continuity of process; an increase in the reliability of the machine; a decrease in the level of human labor intensity in the production; a decrease in the total labor intensity of the product; an increase in the machine technological level; a decrease in the amount of material (metal) in machines; the achievement of the optimal division on machine parts; lower power consumption; reducing machine size, the improvement of the conditions of machine operation and maintenance; raising the security of machine operation and maintenance; the improvement of the appearance (design) of machines; the improvement of the environmental performance of machines.

, The author of the paper will mention the following local partial criteria that are commonly used in the assessment of machines and their components: a high speed of manufacturing operation execution, wide range of adjustment of the working body movement, smooth adjustment of the working body movement, precision and stability of basing, precision of working body movement, the quality of work process, resistance to vibration, high wear resistance, overload protection, low noise, lack of monotony in the service, ease of maintenance, ease of operation, lack of "naughty" mechanisms that require frequent adjustment, ease and convenience of machine adjusting.

Designer selects a list of criteria from the list of global and partial criteria in each case of the technical system design. The basis for selection is the requirements for the designed system. Thus, at the time of selection of design solution the designer wants the system to satisfy maximally all these criteria.

Depending on the selected criteria under the same demands the parameters and technical characteristics of the system may differ. Therefore, the requirements should be formulated, taking into account the place of technical systems in technological cycles.

Reduction of the set of possible options is carried out by consecutive exclusion of the least efficient and least promising options. 
Generally accepted principles of decomposition, according to which the transition from the comparison of alternatives in general to comparison of their individual properties, can be used for such a reduction. The basic idea of this transition bases on the fact that concerning the specific properties it is significantly easier to tell which alternative prevails. Properties of the first hierarchical level can be divided into respective sets of properties, etc. The depth of this division is determined by the desire to reach those properties that are convenient to compare with each other. Comparison of alternatives for individual properties can be accomplished in three ways:

a) based on pair wise (group) comparing the alternatives on the given property;

b) based on the introduction of natural numerical characteristics of the given property;

c) based on the introduction of artificial numerical characteristics of the given property.

TABLE I

CHARACTERISTICS AND SigNIFICANCE OF THE OBJECT

\begin{tabular}{|c|c|c|c|c|}
\hline No. & Characteristic & Meaning 1 & \multicolumn{2}{|l|}{ Meaning 2} \\
\hline 1 & Size & Big, small, medium & & \\
\hline 2 & Color & & & \\
\hline 3 & Shape (appearance) & $\begin{array}{l}\text { Cubic, spherical, elliptical, } \\
\text { pyramid, tetrahedron, the other }\end{array}$ & & \\
\hline 4 & Material & $\begin{array}{l}\text { Steel, cast iron, stone, wood, } \\
\text { plastic }\end{array}$ & $\begin{array}{l}\text { Solid } \\
\text { Soft Porous } \\
\text { Variable }\end{array}$ & $\begin{array}{l}\text { Sticky } \\
\text { Viscous } \\
\text { Abrasive } \\
\text { The chemical composition }\end{array}$ \\
\hline 5 & $\begin{array}{cc}\text { Environmental } & \text { impacts } \\
\text { (location, site, impact) } & \end{array}$ & $\begin{array}{l}\text { Power } \\
\text { Temperature } \\
\text { Electric } \\
\text { Magnetic } \\
\text { Chemical } \\
\text { Gravity }\end{array}$ & $\begin{array}{l}\text { Constant } \\
\text { Variable: } \\
\text { flowing, } \\
\text { growing, } \\
\text { pulsating }\end{array}$ & \\
\hline 6 & Position & $\begin{array}{l}\text { Inclined, vertical, horizontal, } \\
\text { changing (impermanent) }\end{array}$ & & \\
\hline 7 & Structure & Solid, component, variable & & \\
\hline 8 & Process & $\begin{array}{l}\text { Passes } \\
\text { Converts }\end{array}$ & $\begin{array}{l}\text { Parts (fract } \\
\text { Adds (Incr } \\
\text { Sorts } \\
\end{array}$ & \\
\hline 9 & $\begin{array}{l}\text { The phenomena involved in the } \\
\text { process }\end{array}$ & $\begin{array}{l}\text { Overlay of the effects } \\
\text { Phenomena separation } \\
\text { Matches (resonance) }\end{array}$ & $\begin{array}{l}\text { Slow chan } \\
\text { A sharp ch } \\
\text { Power } \\
\text { Hydraulic } \\
\text { Thermal } \\
\text { Hypersoni } \\
\text { Light } \\
\text { Electroma } \\
\text { Gravitatior } \\
\text { Pulsation }\end{array}$ & $\begin{array}{l}\text { f physical state } \\
\text { e in a physical state (blow): } \\
\text { ic }\end{array}$ \\
\hline 10 & The object, which interacts & $\begin{array}{l}\text { Available } \\
\text { Missing }\end{array}$ & & \\
\hline
\end{tabular}

The way of choice for the operation of comparison is generally not specified.

Physical and, as a special case, geometric modeling may be used in the solution of certain problems. An important task of the geometric modeling is to conduct relevant studies aimed at determining the unknown parameters in accordance with the particular technology. The main task of such studies is to find out the extent of similarity or the coefficient of transition from the model parameters to the parameters of the original.
Thus, the sequence of forming of a closed system of criteria can be presented (see Fig. 3).

The characteristic of such a choice is a stepwise selection criterion depending on the problem of research. Depth of stepwise is defined by the complexity of research tasks and demands of the consumer as well. At the final stage of criteria selection, it is appropriate to rank them based on the existing knowledge background. Alternatively, ranking is the attraction of the experienced experts in this field. 
When we use a morphological environment at the stage of designing a mobile rescue robot, it is important to form the purpose or motivation: to get a caterpillar engine design that would have minimal losses at movements. Objective: to be used for tracked vehicles of low power. Involved phenomenon: the transfer of torque from the body to the support surface.

Improvement of the engine crawler will be carried out with the help of algorithm, as it is shown in Fig. 2, based on the existing knowledge base on this problem. The list of attributes is shown in Table 1. The list of criteria is shown in Table 2.
Selection of criteria will be performed on the algorithm presented in Fig. 3.

As the basic criteria the author will choose a common set of criteria, excluding social and information criteria. From the basic criteria (Table 3), some criteria will be translated into additional criteria (Table 4). The author of the paper will provide a procedure of criteria ranking: productivity, reliability, cost of energy to work, cost of materials, manufacturing and maintenance costs, serviceability.

TABLE II

CRITERIA FOR ASSESSMENT OF THE EFFICIENCY OF MACHINES

\begin{tabular}{|c|c|c|}
\hline No. & Groups of criteria & Criteria \\
\hline 1 & $\begin{array}{l}\text { Functional } \\
\text { (purpose), } \\
\text { operating }\end{array}$ & $\begin{array}{l}\text { Productivity } \\
\text { Accuracy (quality) } \\
\text { Reliability (reliability, durability, maintainability) } \\
\text { Special, permeability, flexibility, dynamic performance, } \\
\text { Serviceability }\end{array}$ \\
\hline 2 & Technological & $\begin{array}{l}\text { Labor intensity of production and operation, the ability to part the elements, } \\
\text { continuity of technological cycles }\end{array}$ \\
\hline 3 & Time & $\begin{array}{l}\text { Process cycle time, cycle element time, combining elements of the cycle, } \\
\text { time of support operations }\end{array}$ \\
\hline 4 & Economic & $\begin{array}{l}\text { Costs of materials, energy on construction, reduction of dimensions, thrift, } \\
\text { manufacturing and maintenance costs }\end{array}$ \\
\hline 5 & Anthropometric & Ergonomics (vibration, noise), safety, ecology \\
\hline 6 & Information & Ensuring the performance management, forecasting the state of workflows \\
\hline 7 & Energetic & $\begin{array}{l}\text { Workflow of machines, supplementing the working fluid characteristics, the } \\
\text { operator and maintenance personnel, production and maintenance of machinery }\end{array}$ \\
\hline 8 & Social & Necessity, fashion, beauty, advertising \\
\hline
\end{tabular}

TABLE III

MAIN CRITERIA OF IMPROVEMENT OF THE CATERPILLAR MOVER DESIGN

\begin{tabular}{|l|l|l|}
\hline & Criteria & Basic \\
\hline & Functional & Productivity \\
& (purpose), & Reliability (reliability, durability, maintainability) \\
& operating & Serviceability \\
\hline & Economic & Costs of materials, energy on construction, thrift, manufacturing and maintenance costs \\
\hline
\end{tabular}

TABLE 4

ADDITIONAL CRITERIA OF IMPROVEMENT OF THE CATERPILlAR MOVER DESIGN

\begin{tabular}{|l|l|l|}
\hline & Criteria & Additional \\
\hline Technological & $\begin{array}{c}\text { Labor intensity of production and operation, the ability to part the elements, continuity of } \\
\text { technological cycles }\end{array}$ \\
\hline Time & $\begin{array}{c}\text { Process cycle time, cycle element time, combining elements of the cycle, time of support } \\
\text { operations }\end{array}$ \\
\hline Energetic & $\begin{array}{c}\text { Workflow of machines, supplementing the working fluid characteristics, the operator and } \\
\text { maintenance personnel, production and maintenance of machinery }\end{array}$ \\
\hline & Anthropometric & Ergonomics (vibration, noise), safety, ecology \\
\hline
\end{tabular}

Let us carry out the procedure of ranking for additional criteria: time of technological cycle, time of cycle elements, combining of the cycle elements, time of supporting operations, complexity of manufacturing and maintenance, the ability to part the elements, the continuity of the cyclical process, ergonomics (vibration, noise), safety, environmental implications, machine workflow, the characteristics of the working fluid, the operator and maintenance personnel, production and maintenance of machinery. The author of the paper will carry out the screening of secondary criteria. 
The next step of improvement is to check feature compatibility. From Table 1 the author of the paper chooses such features as size, materials, processes, phenomena involved in the process. Based on the comparison of the specifications of features, it can be stated that they are all compatible.

From table attributes the author chooses: size - medium, material - steel, process - converts, phenomenon - blending of the effects, slow change in the physical state.

Based on the existing knowledge base [12-14], the author carries out the improvement of existing designs.

The technical result is achieved by the fact that the caterpillars with the rubber and metal hinge, which have tracks with combs and lugs with holes, in which fingers are mounted concentrically with vulcanized rubber bushings, pressed into the holes, according to the improvement, the fingers and holes have elliptical cross cuts, and fingers are set so that the next major pin of these cross cuts are equal to acute angles, which are directed towards the reduction of their internal folding of tracks.

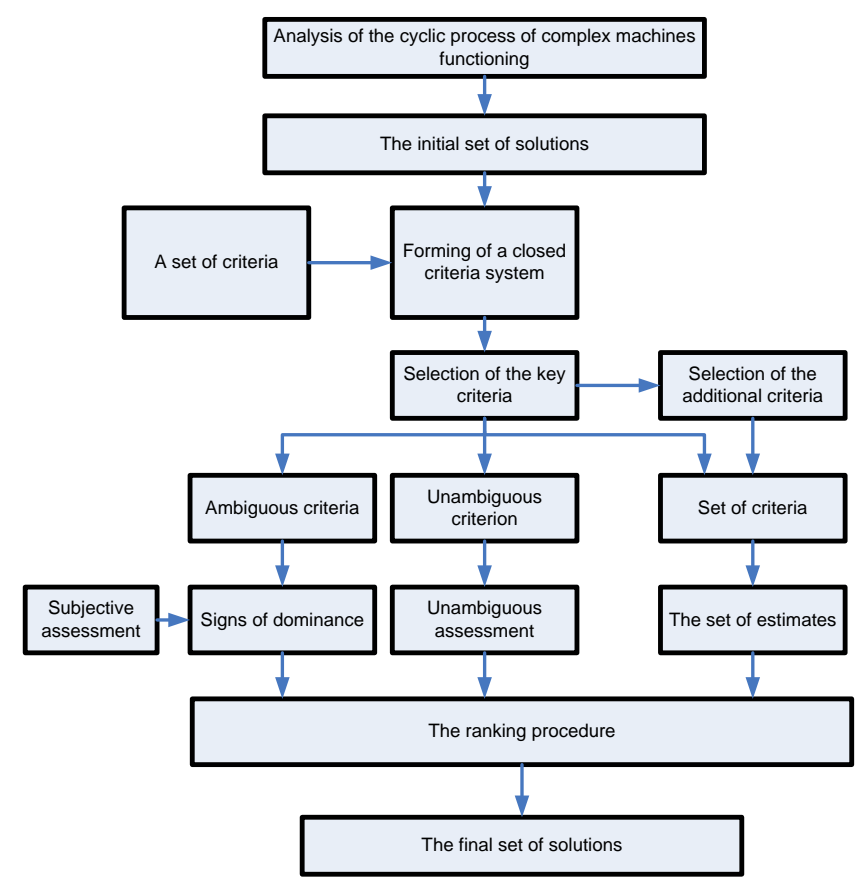

Fig. 3 The sequence of forming of a closed system of criteria.

In the case of damage of leading and guiding wheels by the contour elements of caterpillar outline and extreme roller bearings, there is an internal folding of track 1 (arrows B). In this case, the angles between the nearest major pins 7 and 8 (9 and 10) of cross cuts of fingers 5 and holes 4 reduce. Thanks to this, fingers 5 and holes 4 have elliptical cross cuts, rubber bushings 6 not only twist, but also compress. All zones of rubber bushings 6 are twistable, but only the area is compressible that is located between major half pin 7 and 8 , fingers 5 (within their limits) and holes 4 to help to reduce the angles between the half pin 7 and 8 (9 and 10). At the internal folding of tracks these zones are large enough, that is, hardness is relatively small. While driving the vehicle on the ground with low carrying capacity the roller bearings and tracks 1 are located under them deep into the soil. Tracks 1 are located between the roller bearings, while having an external assembly (reverse compilation by arrow B). It means that the angle between the nearest major half pin 7 and 8 (9 and 10) of cross cuts of fingers 5 and holes 4 increases.

The zones of rubber bushings 6 , which are located between the major half pins 7 and 8 fingers 5 (within the last) and holes 4 in the direction of the growth of the angles between half pins 7 and 8 (9 and 10) compresses. At the external folding of tracks 1, these zones are small (compared to zones in the internal folding of tracks 1 ), which provides a greater rigidity. The last ensures a more even distribution of the specific pressure on the ground along the bearing section of caterpillar; a reduction of the deepening into the soil of the roller bearings and an increase in a cross-country ability of the vehicle.
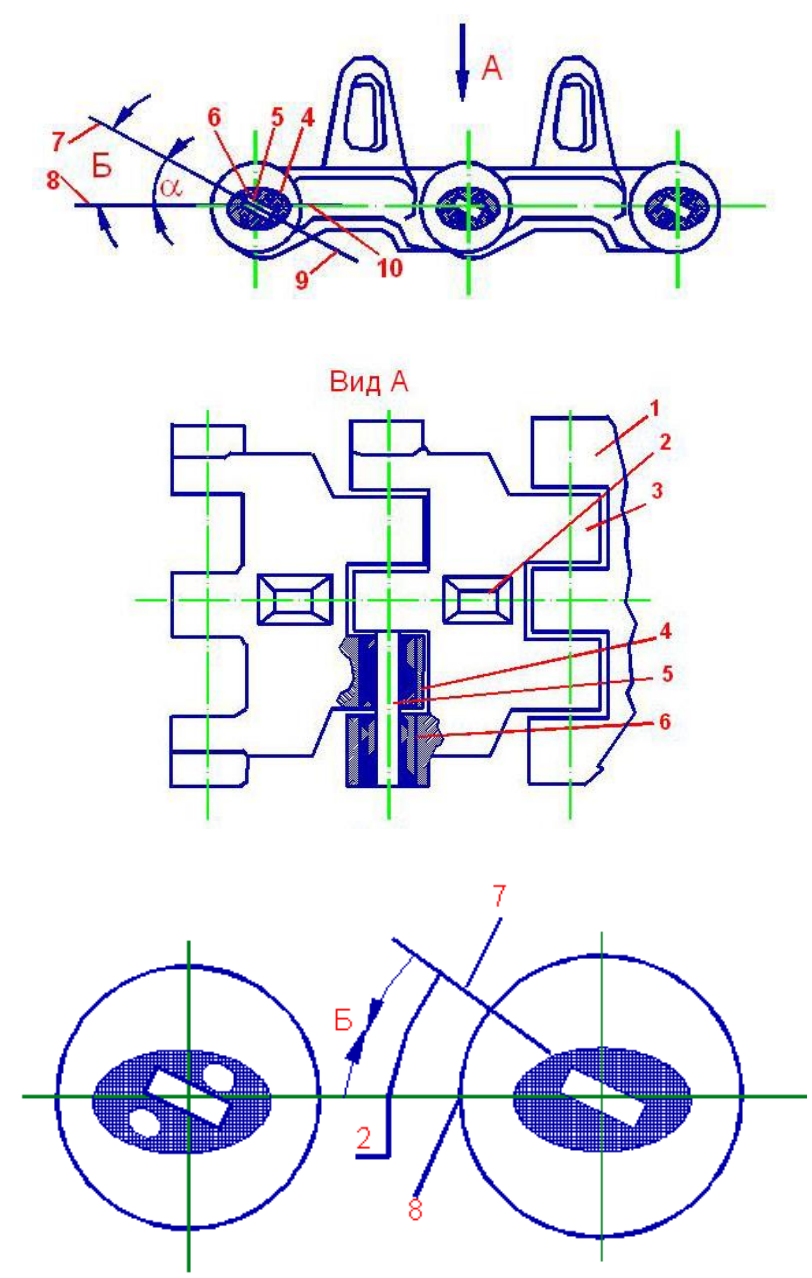

Fig. 4. The advanced design of the caterpillar tracks.

\section{CONCLUSIONS}

By the creation of mobile rescue robots it is offered to use the morphological environment, which models the work of the human brain. The usage of the morphological environments will allow regulating and systematizing large knowledge arrays, which are necessary for the projecting of vehicles and 
mechanisms. The morphological environment has to be of a particular structure. By the creation of the new construction it is expedient to use the specialized algorithm of the synthesis and improvement of the existing vehicles and mechanisms with the use of global and local efficiency criteria. The given example of the improvement of the construction of the caterpillar motor of the mobile robot proves the efficiency of the use of the morphological environment for the design of new vehicles and mechanisms.

\section{REFERENCES}

[1] "Roboty spasajut zhizni." Internet: http://thankve-minpa.livejournal com/36926.html, Dec. 13, 2010 [Nov. 25, 2013].

[2] "14 udivitelnyh robotov-spasatelej." Internet: http://robotor.ru/2011/04/ 14/rescue-robots/, Apr. 14, 2011 [Nov. 25, 2013].

[3] E.U. Isaev, N.S. Solomatin, V.V. Kovtun, V.M. Karpov. Etapy razrabotki legkovogo avtomobilja. Toljatti: TGU, 2004, pp.113.

[4] E. Molnina. M. Kartukov. "Problema intellektualnogo analiza tekstov", Integration of Science and Education, vol. 11, 2007, pp.136-137.

[5] A. Malyh. "Predstavlenie znanij i semantičeskoje programmirovanije." Cand. phis-math. thesis, University of Irkutsk, 2005

[6] T. Berners-Lee. J. Hendler. O. Lassila. "The Semantic Web." Scientific American, May 2001, pp. 29-37.

[7] M. Movsumzade. "Ekonomiko-matematičeskie modeli v optimizaci upravleniâ hozajstvennymi potokami predpriatij v usloviah ekstremalnoj ekonomiki." Neft, gaz i biznes, vol. 6, 2001, pp. 23-26.

[8] A. Mancivoda. A. Malyh. "Predstavlenie i obrabotka znanij v Internete." Informacionnye sistemy i logika, vol. 2, pp. 111, 2005.
[9] R. V. Zinko. "Morfologichne seredovise dla modeluvanna tehnichnih sistem." in Proc. MSUIML-10, 2011, pp. 193-194.

[10] R. Zinko. "Morfologichne seredovise dla modeluvanna tehnichnih sistem." Naukovi notatki, vol. 38, 2012, pp. 61-66.

[11] I.T. Glebov. V.V. Gluhih. I.V. Nazarov. Nauchno-tehnicheskoe tvorchestvo. - Ekaterinburg: Ural. gos. lesotehn. un-t., 2002, pp 264.

[12] B. Šarov, O. Makovejčuk, R. Zinko. "Mobilnij ohoronnij robot iz sistemov tehnichnogo zoru." Proektuvanna, virobnictvo ta ekspluatacia avtotransportnih zasobiv i poezdiv, vol. 19, 2011, pp. 285-290.

[13] R. Zinko. E. Suloeva. "Mobilni roboti v sistemi požežnoi ohoroni." Naukovij visnik NLTU Ukraini, vol. 21.17, 2011, pp. 132-138.

[14] R. Zinko. E. Suloeva. "Ekonomična efektivnist požežnoi ohoroni pri vikoristanni mobilnih robotiv." Naukovij visnik NLTU Ukraini, vol. 22.10, 2012, pp. 320-329.

Roman Zinko graduated from Lviv Polytechnic University (Ukraine) in 1992, Candidate of Technical Sciences. He is an Assistant Professor at the Institute of Engineering Mechanics and Transport, Department of Mechanical Engineering. In 2013 he finished doctoral studies. The theme of the Doctoral Thesis concerns the problems of mechanics: The Use of Morphological Environment for the Research of Technical Systems.

Roman Zinko works on the creation of energy saving machines and mechanisms in the technological processes. Among the researched objects, there are means of transport, robots crushers, low-speed wind-driven power units. He has more than 110 scientific, scientific and methodological papers and patents.

Address: LPNU, apt.8 Bandera Street, Lviv, Ukraine

E-mail: rzinko@gmail.com 


\section{Safety of Technogenic Environment}

5

2014/ 